\title{
Intensity of Fiscal Illusion in Local Self-Government in Poland: Trends and Threats
}

\author{
Beata Guziejewska
}

\begin{abstract}
This article presents the preliminary results from the quantitative part of the broader study the aim of which is to investigate the consequences of the current system of financing local self-government entities in Poland in the context of fiscal illusion. This system of revenue is characterized by low fiscal importance of the local taxes and fees and a high contribution of transfers from the central budget: general grants, specific grants, shares in the PIT (Personal Income Tax) and CIT (Corporate Income Tax). The study used an improved questionnaire with closed-ended questions based on the five-level Likert scale. This article presents the part relating to the intensity of fiscal illusion. The results demonstrate the low esteem of "own revenues" in the eyes of the councilors. The councilors are against raising local taxes and tend to demand an increase in the transfer revenues for the municipal budgets, which reinforces demanding attitudes and hinders local democracy. The question of whether this will play an important role in the perpetuation of fiscal illusion and thus sustain a loss in local responsibility, democracy and civil society is still an open one.
\end{abstract}

Index Terms-Public finance, local government finance, fiscal illusion, fiscal decentralization.

\section{INTRODUCTION}

Fiscal decentralization is not, in practice, an easy process and should be viewed as a comprehensive system. The last two decades in Poland have been the time of a public finance decentralization process in which public tasks have been decentralized but there has been a problem with the adequate decentralization of taxes. The difficulties with tax assignment have resulted in the use of tax sharing as an important source of local revenue and in a very weak local tax system. The lack of correlation between the type and level of revenue and the structure and level of local expenditure has negative political, economic and social consequences. The specific detachment of expenditures from the local taxes and fees may lead to various fiscal illusions and a higher local public debt. The article covers the part of the research project based on the questions directly concerning the intensity of misperception and fiscal illusions among the councilors. The concept of the study is based on the assumption that it is difficult to expect the average voter to understand complex mechanisms of public life and finance in the system of representative

Manuscript received April 2016. This work was funded by the Polish National Science Center, "The role of the system of financing local government in the creation and perpetuation of fiscal illusion. Complementarity of qualitative and quantitative methods" under grant 2014/13/B/HS4/00162

The Author is with the Department of Public Finance, University of Lodz, Rewolucji 1905 r. 39 st., 90-214 Lodz, Poland (e-mail: beata.guziejewska@uni.lodz.pl). democracy and the contemporary globalized environment. It is important, however, that the representatives of the citizens, the councilors, should understand such mechanisms. Therefore, the subject of the research has been defined as fiscal illusions among the councilors of several largest cities in Poland. The presence of fiscal illusions among the councilors translates directly into the origin of fiscal illusions in public life.

\section{THEORETICAL BACKGROUND}

The literature on local self-government finance is abundant with many detailed problems. The main role is played by the fiscal federalism theory [1], [2]. In practice, there is a problem of disparity between the sources of revenue and the necessary expenditure; it is sometimes said that the assigned revenues cannot 'catch up with' the decentralization of tasks. In the Polish literature, the focal point of interest also lies in the fiscal and financial independence of local government. The traditional fiscal autonomy of sub-central governments and their sources of revenues were described by A. Shah [3]. The need for supplementary and redistributive functions of the central budget results in too large a scope of transfers. In such a system, the so-called Wicksellian relations are broken; the lack of correlation between the level of charges and local taxes that the residents are willing to pay for local services and goods has various negative consequences related to fiscal illusions (traditionally associated with indirect taxes).

The foundations for the theory of fiscal illusions were laid by two Italian economists, A. Puviani and M. Fasiani [4]. An illusion is a false belief, a distorted interpretation of things and phenomena [5]. Initially, the problem was described in connection with taxation, now it has also implications for intergovernmental fiscal relations [6]. According to $\mathrm{P}$ Mourao, fiscal illusions occur when the taxpayers and electors are not aware of the fiscal reality. The phenomenon can also be understood as a result of interactions between rational agents who try to maximize their utilities [7]. As N. Bosch and J. S. Pandiello point out, "Political economy suggests that the expected outcomes of actions taken by public agents (politicians and bureaucrats) in the economic area are far from being exogenous and unlikely to depend exclusively on the taxpayers-voters will" [8].

Dollery and Worthington [9] presented an interesting systematization of trends in the empirical research in fiscal illusion. In the 1990s, the backdrop for the categorization was provided in the form of noticeable tendencies of many countries to foster fiscal responsibility and transparency of public finance. They identified five main approaches in the empirical research: revenue-complexity hypothesis, 
revenue-elasticity hypothesis, flypaper effect, renter illusion and debt illusion. Since 1960 attempts have been made to quantify and empirically study [10] the scope of fiscal illusion in nearly 70 countries. In the field of local government finance, empirical research has been dominated by the problems of the sources of a more than proportional rise in local public spending. The phenomenon known as the flypaper effect is associated with the problem of fiscal illusion. However, the recent empirical research into the local government finance of such countries as Australia [11], the Republic of South Africa [12] and the United States [13] have not yielded any conclusive results. In his classic article "On the Nature and Measurement of Fiscal Illusion: A Survey," Oates [14] demonstrated the ambiguous relations between fiscal illusion and growing public spending as he pointed to various forms of local budget processes as a possible cause of excessive budget growth. Different historical conditions, debt limits and constraints at the local government tier (agenda-control model of the flypaper theory) and the role of the bureaucratic apparatus should also be mentioned in this context.

The literature and the ideas of the 1950's and 1960's are referred to as the so-called first-generation theory of fiscal federalism. The second-generation theory draws on two basic sources: 1 . the works into public choice and political economy and 2. the extensive literature on the problems of information. The former source largely focuses on political processes and the behavior of political agents [15].

The problem of fiscal illusion at the local government tier is increasingly important in view of the ongoing process of transferring public tasks to the lower tiers, which, in turn, increases the redistribution of public funds at the local level. It is difficult to expect the so-called average voter to understand complex mechanisms of public life and finance in the system of representative democracy. There has been little research into fiscal perception, illusion and voting on the local scale but some of the empirical evidence supports the hypothesis that fiscal perception affects voters' behavior [16].

It is important, however, that councilors, representatives of the citizens, should understand such mechanisms. Therefore, the subject of the research has been defined as fiscal illusion among the councilors of several largest cities in Poland.

\section{TAXES OR GRANTS: DOES IT REALLY MATTER?}

Appendix 1 to the article presents a picture of local self-government revenues in Poland. As the statistics demonstrate, the system of financing local government in Poland relies heavily on the so-called transfer revenues. The revenues, which are similar in their economic nature, include general subsidies, earmarked grants and shares in the state taxes. In the theory of fiscal federalism, these revenues are classified as transfer revenues from the central budget. In Poland, according to the law and statistics, shares in the PIT (Personal Income Tax) and CIT (Corporate Income Tax) are treated as "own", internal revenues.

Despite its many advantages (recognized when the decision was taken to use large shares in the PIT and CIT), the system based on transfers results in many adverse consequences from the economic, social and political points of view. The recognition of many benefits of transfer revenues was a conscious element in designing the revenue system and financial policy in Poland. Today, however, the system is ripe for change due to the imbalance between the sources of revenue - "taxes" versus "transfers". It is a challenge for the current financial policy of the state towards local governments to strengthen their financial situation by increasing the revenue of typically tax nature in order to decrease the amount of transfer revenues in the financing structure of local government revenues. The problem was described in details in the relevant, earlier work aforementioned.

The foundations for a successful decentralization and fiscal autonomy are laid on local taxes and fees. Otherwise there is a threat of perpetuation of fiscal illusions. As the World Bank concludes, local taxes are crucial for decentralization and grants play an additional, supplementary role [17].

\section{SElECTED RESUlts From THE QUESTIONNAIRE}

The intensity of fiscal illusions was investigated using an improved (when compared to the earlier part of the research) questionnaire with questions based on the five-level Likert scale. This questionnaire was sent by email to the councilors of seven largest, in terms of population, cities in Poland (with the exception of the capital city of Warsaw). Although the number of councilors in the 2014-2018 term of office exceeded 250, the questionnaires were sent to 242 councilors in the end. The response rate was low and stood at about $23 \%$. There was a problem with many email addresses (some of them were difficult to find, many emails were not delivered for various reasons reported by Outlook). This stage of the research took place in December 2015/January 2016. The number of questionnaires with responses was 56 . From the perspective of a specific situation in Poland and from the perspective of the experience after the previous stage of the research (in-depth structuralized interviews), it is possible to list some reasons for such a low response rate. These include:

1) the problems in questioners are difficult and remain a "sore point",

2) the councilors were afraid of how the answers could be used; probably they suspected the purposes that might not be purely scientific,

3) some of the councilors were elected to the parliament and refused to participate in the study,

4) the political situation after the parliamentary elections in October 2015 was difficult and local self-governments seemed to be even more politicized then before,

5) financial affairs were even more "sensitive" in the context of the new state government in Poland and its new fiscal policy.

Another source of the problems may lie in the level of legal knowledge about local finance, which was evident in the first, pre-test part of the research. Most of the councilors had very little general knowledge about finance. They declared, however, that they were interested in finance and budgeting. Unfortunately, they were not aware of the importance of local taxes, as they listed grants and shares in state taxes as the main source of budgeting. A more general approach to the problem 
leads to a conclusion that the prevalence of quantitative methods, based on financial data, in public finance may result from the challenges that are posed by qualitative methods. The councilors are in fact local politicians, which makes them very specific and rather "difficult" respondents.

The intensity of fiscal illusions was measured in selected questions. These were:

Q1: Do you or do you not agree with the following statement: in order to increase revenue in the city budget, the grants from central budget should be raised.

Q2: Do you or do you not agree with the following statement: in order to increase revenue in the city budget, the shares in PIT and CIT should be raised.

Q3: Do you or do you not agree with the following statement: in order to increase revenue in the city budget, the local taxes and fees should be raised.

Q4: Do you think that local self-government should have more competence to decide on the level of local taxes and fees?

Q5: Do you think that the cities at risk of bankruptcy should receive financial assistance from the state budget?

Q6: Do you think that the financing from grants from the state budget should rise at the cost of reducing the financial independence of local self-government?

The answers are presented in Table I. The arrows in the first column suggest a greater illusion with a higher number of answers in selected direction.

TABLE I: THE INTENSITY OF ILLUSIONS IN ABSOLUTE TERMS

\begin{tabular}{|l|c|c|c|c|c|}
\hline Questions & No & $\begin{array}{c}\text { Rather } \\
\text { No }\end{array}$ & $\begin{array}{c}\text { I have no } \\
\text { view }\end{array}$ & $\begin{array}{c}\text { Rather } \\
\text { Yes }\end{array}$ & Yes \\
\hline 1. => & 4 & 14 & 0 & 18 & 20 \\
\hline 2. => & 2 & 3 & 3 & 16 & 32 \\
\hline $3 .<=$ & 24 & 16 & 3 & 12 & 1 \\
\hline $4 .<=$ & 1 & 4 & 8 & 23 & 20 \\
\hline 5. => & 10 & 20 & 9 & 16 & 1 \\
\hline 6. $=>$ & 25 & 24 & 3 & 2 & 2 \\
\hline
\end{tabular}

Source: own elaboration based on questionnaire.

The answers to questions 1, 2 and 3 indicate a high intensity of fiscal illusion among councilors. 20 of the 56 respondents would definitely increase grants in order to raise revenues in local self-government budgets, and 38 respondents answered "yes" and "rather yes". The sum of such answers to the second question concerning shared taxes is 48 , so in this area the intensity of fiscal illusion is even greater. In the area of local taxes and fees the assessment of illusion is similar because 40 respondents were against raising local taxes. These results suggest that the councilors are not aware of the importance of local taxes and fees for local autonomy. Although the councilors are against higher local taxes, the responses to question 4 indicate that they think that local governments should have more possibilities and competence to decide on the level of taxation. This may suggest that on the one hand they would like to have more competence, on the other hand, however, they would rather not take unpopular decisions. The councilors would prefer the state to take decisions about higher taxes. Such a conclusion can also be drawn from the first stage of the research (direct in-depth interviews).

In the case of question number 5, 30 respondents answered against any form of bailout from state budget. There is an interesting situation with the last of the selected questions. Most of the councilors (49) are against increasing grants if they should result in reducing financial independence, as mentioned in the question. In the case of questions 1 and 2 most of the responses were in favor of transfers.

The last question reveals the lowest intensity of fiscal illusions. The problem is that this is in contradiction to the answers to questions 1 and 2 . This can be assessed as a fiscal illusion per se. All the answers confirm the assumed presence of fiscal illusions resulting from a high contribution of transfers from the central budget: general grants, specific grants and shares in the PIT and CIT.

Table II presents the results in relative numbers. They confirm the highest intensity of illusions in the area characterized by such transfers as shares in the PIT and CIT and in the area associated with grants, especially if the answers to the first and the last questions are compared. $68 \%$ $(36+32)$ of the respondents are characterized by a high level of fiscal illusion in the area of grants and $86 \%(57+29)$ in the area of shared taxes which, according to the fiscal federalism theory, are also, in fact, transfers from the state budget. The best situation occurs in the case of question 4 where $77 \%$ $(36+41)$ of the respondents are in favor of fiscal independence (but only to an extent where there is no need to decide on a rise in local taxes and to take the responsibility for this decision).

TABLE II: THE INTENSITY OF ILLUSIONS IN RELATIVE TERMS

\begin{tabular}{|l|c|c|c|c|c|}
\hline Questions & No & $\begin{array}{c}\text { Rather } \\
\text { No }\end{array}$ & $\begin{array}{c}\text { I have no } \\
\text { view }\end{array}$ & $\begin{array}{c}\text { Rather } \\
\text { Yes }\end{array}$ & Yes \\
\hline $1 .=>$ & $7 \%$ & $25 \%$ & $0 \%$ & $32 \%$ & $36 \%$ \\
\hline $2 .=>$ & $4 \%$ & $5 \%$ & $5 \%$ & $29 \%$ & $57 \%$ \\
\hline $3 .<=$ & $43 \%$ & $29 \%$ & $4 \%$ & $22 \%$ & $2 \%$ \\
\hline $4 .<=$ & $2 \%$ & $7 \%$ & $14 \%$ & $41 \%$ & $36 \%$ \\
\hline $5 .=>$ & $17 \%$ & $36 \%$ & $16 \%$ & $29 \%$ & $2 \%$ \\
\hline 6. => & $44 \%$ & $43 \%$ & $5 \%$ & $4 \%$ & $4 \%$ \\
\hline
\end{tabular}

Source: own elaboration based on questionnaire.

What appears to be an interesting issue is a link between the intensity of the illusions and the political affiliation declared by councilors in the questionnaire. There is a similar problem with regard to the councilors' experience (number of terms of office). Both of these issues will be studied in the future.

The initial results presented in this article seem to contradict the main paradigm of decentralization. The literature describes the classic concept of "the benefit principle" in public finance. It says that people who benefit from particular services should bear its cost [18]. It seems reasonable to broaden the issue of decentralization and to assign the responsibilities associated not only with expenditures but also with revenues.

\section{CONClusions}

The findings reveal high intensity of fiscal illusions in the local self-government system. The opinions presented by the councilors suggest the misperception of the public finance system. The councilors are against raising local taxes and yet they tend to request higher transfer revenues for the municipal budget, which reinforces demanding attitudes. They simply expect more shares in the PIT and CIT, a higher general grant and, at the same time, they are against levying higher local taxes. The respondents support the idea of a wider fiscal 
independence and autonomy of local self-government budgets, but they show reluctance to raise local taxes. In the broad sense, the councilors expect the state to solve some problems, take decisions and also provide the money. There is unfortunately a lack of some wider reflection on the fact that the money from grants comes from the taxes collected at the state level. The conclusions are very important for the future of fiscal policy in Poland. It is also important for local democracy as fiscal illusions tend to hinder it.
Fiscal illusions are very difficult to study, but such research is important for public finance, which is a social science. The low response rate is a consequence of the specifics of the research the main aim of which was to identify and measure illusions, that is misunderstandings and misuses of financial instruments and phenomena in the public sector in a non-market economy. The area of finance with political dimensions and associations is very difficult to investigate but definitely deserves further study.

\section{APPENDIX 1}

TABLE III: REVENUE OF LOCAL GOVERNMENT UNITS BUDGETS IN SELECTED YEARS

\begin{tabular}{|c|c|c|c|c|c|c|}
\hline \multicolumn{2}{|l|}{$\begin{array}{l}\text { Specification } \\
\text { (all in } \mathrm{mln} \mathrm{zl})\end{array}$} & Total & Gminas & Cities with powiat status & Powiats & Voivodships \\
\hline \multirow{3}{*}{ Total } & 2005 & 102912 & 45813 & 36270 & 13763 & 7066 \\
\hline & 2010 & 162797 & 72311 & 53886 & 22496 & 14104 \\
\hline & 2013 & 183458 & 80043 & 64217 & 23078 & 16121 \\
\hline \multirow{3}{*}{$\begin{array}{l}\text { Own revenue } \\
\text { of which: }\end{array}$} & 2005 & 54889 & 22300 & 23984 & 4018 & 4587 \\
\hline & 2010 & 78588 & 32264 & 34284 & 6337 & 5703 \\
\hline & 2013 & 91800 & 38546 & 40059 & 6894 & 6303 \\
\hline \multirow{4}{*}{$\begin{array}{l}\text { Share in income taxes } \\
\quad(\mathrm{PIT} \text { and CIT })\end{array}$} & 2005 & 22789 & 6713 & 10244 & 1896 & 3936 \\
\hline & 2010 & 33016 & 10698 & 14543 & 2925 & 4850 \\
\hline & 2012 & 37613 & 12866 & 15872 & 3486 & 5389 \\
\hline & 2013 & 38761 & 13566 & 16411 & 3668 & 5116 \\
\hline \multirow{3}{*}{ Tax on real estate } & 2005 & 11669 & 6995 & 4674 & $\mathrm{x}$ & $\mathrm{x}$ \\
\hline & 2010 & 15122 & 9060 & 6062 & $\mathrm{x}$ & $\mathrm{x}$ \\
\hline & 2012 & 17603 & 10608 & 6995 & $\mathrm{x}$ & $\mathrm{x}$ \\
\hline \multirow{4}{*}{ Agricultural tax } & 2005 & 967 & 950 & 16,9 & $\mathrm{x}$ & $\mathrm{x}$ \\
\hline & 2010 & 989 & 974 & 15,3 & $\mathrm{x}$ & $\mathrm{x}$ \\
\hline & 2012 & 1546 & 1517 & 29,0 & $\mathrm{x}$ & $\mathrm{x}$ \\
\hline & 2013 & 1665 & 1635 & 30,3 & $\mathrm{x}$ & $\mathrm{x}$ \\
\hline \multirow{4}{*}{ Tax on means of transport } & 2005 & 662 & 385 & 277 & $\mathrm{x}$ & $\mathrm{x}$ \\
\hline & 2010 & 857 & 561 & 296 & $\mathrm{x}$ & $\mathrm{x}$ \\
\hline & 2012 & 917 & 624 & 292 & $\mathrm{x}$ & $\mathrm{x}$ \\
\hline & 2013 & 941 & 639 & 302 & $\mathrm{x}$ & $\mathrm{x}$ \\
\hline \multirow{4}{*}{ Tax on civil law transactions } & 2005 & 1195 & 438 & 756 & $\mathrm{x}$ & $\mathrm{x}$ \\
\hline & 2010 & 1893 & 791 & 1102 & $\mathrm{x}$ & $\mathrm{x}$ \\
\hline & 2012 & 1492 & 688 & 804 & $\mathrm{x}$ & $\mathrm{x}$ \\
\hline & 2013 & 1629 & 710 & 919 & $\mathrm{x}$ & $\mathrm{x}$ \\
\hline \multirow{3}{*}{ Stump duty } & 2005 & 519 & 294 & 225 & $\mathrm{x}$ & $\mathrm{x}$ \\
\hline & 2010 & 509 & 226 & 283 & $\mathrm{x}$ & $\mathrm{x}$ \\
\hline & 2012 & 485 & 203 & 282 & $\mathrm{x}$ & $\mathrm{x}$ \\
\hline \multirow{3}{*}{ Revenue from property } & 2010 & 6354 & 2628 & 3276 & 305 & 143 \\
\hline & 2012 & 6945 & 2737 & 3692 & 315 & 201 \\
\hline & 2013 & 7563 & 2766 & 4276 & 353 & 169 \\
\hline \multirow{4}{*}{$\begin{array}{l}\text { Funds for financing of own tasks } \\
\text { from other sources }\end{array}$} & 2005 & 2797 & 1742 & 605 & 280 & 170 \\
\hline & 2010 & 2476 & 1408 & 786 & 214 & 67,5 \\
\hline & 2012 & 1966 & 1310 & 415 & 148 & 92,6 \\
\hline & 2013 & 1396 & 868 & 361 & 106 & 62,1 \\
\hline \multirow{4}{*}{ Specific grants } & 2005 & 15567 & 7432 & 605 & 280 & 170 \\
\hline & 2010 & 37038 & 17370 & 786 & 214 & 67,5 \\
\hline & 2012 & 39665 & 17235 & 415 & 148 & 92,6 \\
\hline & 2013 & 40401 & 16704 & 361 & 106 & 62,1 \\
\hline \multirow{4}{*}{$\begin{array}{l}\text { General subvention from the } \\
\text { state budget }\end{array}$} & 2005 & 32456 & 16080 & 8325 & 6699 & 1350 \\
\hline & 2010 & 47171 & 22676 & 11804 & 9750 & 2942 \\
\hline & 2012 & 50658 & 24649 & 13280 & 10222 & 2506 \\
\hline & 2013 & 51257 & 24793 & 13547 & 10278 & 2639 \\
\hline
\end{tabular}

Source: Statistical Yearbook of the Republic of Poland, Warsaw 2014, pp. 656-657.

\section{APPENDIX 2}

The chosen questions from the questionnaire:

1. Do you or do you not agree with the following statement: in order to increase revenue in the city budget, the grants from central budget should be raised. 


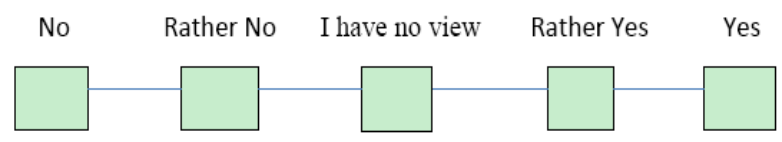

2. Do you or do you not agree with the following statement: in order to increase revenue in the city budget, the shares in PIT and CIT should be raised.

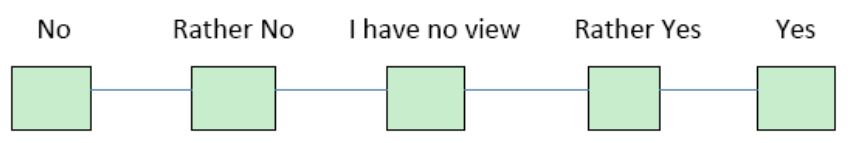

3. Do you or do you not agree with the following statement: in order to increase revenue in the city budget, the local taxes and fees should be raised.

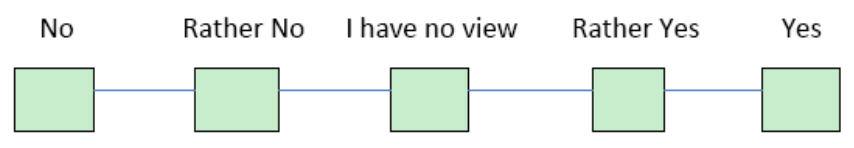

4. Do you think that local self-government should have more competence to decide on the level of local taxes and fees?

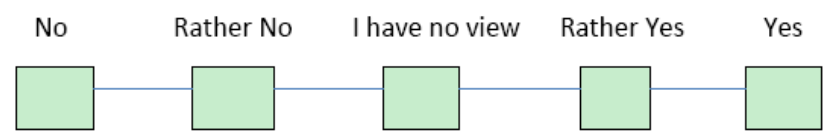

5. Do you think that the cities at risk of bankruptcy should receive financial assistance from the state budget?

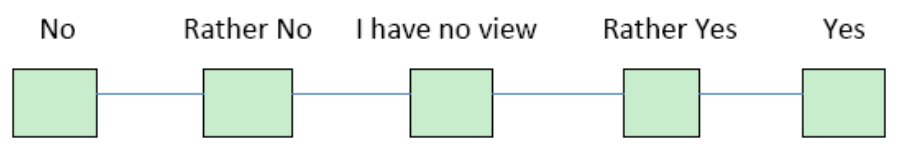

6. Do you think that the financing from grants from the state budget should rise at the cost of reducing the financial independence of local self-government?

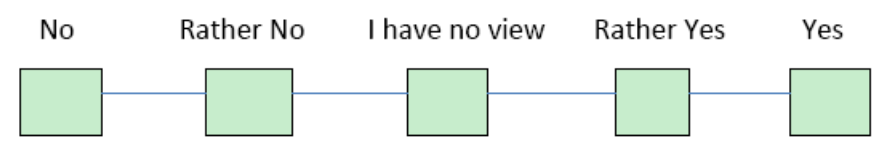

\section{REFERENCES}

[1] R. A. Musgrave and P. B. Musgrave, Public Finance in Theory and Practice, 4th Edition, McGraw-Hill Book Company, 1973, pp. 513-585.

[2] J. E. Stiglitz, Economics of the Public Sector, W. W. Norton \& Co., 3rd Edition, 2000, pp. 631-664.

[3] A. Shah, "The reform of intergovernmental fiscal relations in developing \& emerging market economies," Policy and Research Series, no. 23, World Bank, 1994.

[4] J. M. Buchanan, Finanse Publiczne W Warunkach Demokracji, Polish edition, Warsaw: PWN, 1997, pp. 158-171.

[5] B. Guziejewska, "Theoretical dimensions of fiscal illusions in local government finance," Journal of Economics, Business and Management, vol. 4, no. 3, pp. 215-218, March 2016.

[6] B. Guziejewska, "Intergovernmental fiscal relations. Theoretical aspects and Poland's experience," Financial Internet Quarterly e-Finanse, vol. 9, no. 3, 2013.

[7] P. Mourao, "Fiscal illusion causes fiscal delusion-please be careful," Global Security, Safety, and Sustainability, vol. 92, p. 233, 2010.

[8] N. Bosch and J. S. Pandiello, "Politics and finance in Spanish municipalities," Hacienda Publica Espanola/Review of Public Economics, vol. 212, no. 1, Instituto de Estudios Fiscales, p. 52, 2015.

[9] B. Dollery and A. Worthington, "The empirical analysis of fiscal illusion," Journal of Economics Surveys, vol. 10, no. 3, Blackwell Publishing, pp. 261-297, 1996

[10] P. Mourao, "Towards a fiscal illusion index," Munich Personal RePEc Archive Paper No. 9760, 2007.

[11] A. C. Worthington and B. Dollery, 'Fiscal illusion and the Australian local governments grants process: How sticky is the flypaper effect," Public Choice, vol. 99, no. 1/2, pp. 1-13, 1999.

[12] H. Amusa, R. Mabunda, and R. Mabugu, "Fiscal illusion at the local sphere: An empirical test of the flypaper effect using South African municipal data," Working Paper No 72, Financial and Fiscal Commission, pp. 1-23, 2008.

[13] H. S. Banzhaf and W. E. Oates, "On fiscal illusion and Ricardian equivalence in local public finance," Georgia State University, Andrew Young School of Policy Studies, Research Paper Series, Working Paper, pp. 12-15, 2012.

[14] W. E. Oates, "On the nature and measurement of fiscal illusion: A Survey," in Taxation and Fiscal Federalism: Essays in Honour of Russell Mathews, Brennan et al., Eds. Australian National University Press, Sydney, 1988, pp. 65-82.

[15] W. E. Oates, "Toward a second-generation theory of fiscal federalism," International Tax and Public Finance, vol. 12, Springer Science + Business Media, Inc., pp. 349-373, 2005.

[16] N. Bosch and J. Suárez-Pandiello, "Fiscal perception and voting," Environment and Planning C: Government and Policy, vol. 11, pp. 233-238, 1993.

[17] Intergovernmental Fiscal Relations, section Decentralization, The World Bank Group. [online] Available: http://www1.worldbank.org/publicsector/decentralization/fiscal.htm

[18] J. E.Greene, Public Finance. An International Perspective, World Scientific Publishing Co., pp. 299-300, 2012.

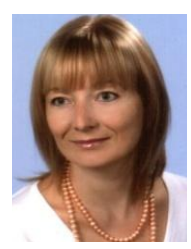

Beata Guziejewska, $\mathrm{PhD}$, associate professor in Public Finance Department, Institute of Finance, University of Lodz, Poland. Her interests include public finance, fiscal decentralization, management of public revenue and expenditure, globalization; the current research interests focus on problems of intergovernmental fiscal relations, fiscal illusions in decentralized public systems and performance budgeting. 